\title{
Pollination of Pagamea duckei Standl. (Rubiaceae): a functionally dioecious species
}

\author{
Mário Henrique Terra-Araujo ${ }^{1,3}$, Antonio Carlos Webber $^{2}$ \& Alberto Vicentini ${ }^{1}$ \\ IPrograma de Pós-graduação em Botânica - PPG-BOT, Instituto Nacional de Pesquisas da Amazônia- \\ INPA, Av. André Araujo, 2936, Manaus, AM, Brasil \\ ${ }^{2}$ Departamento de Biologia, Universidade Federal do Amazonas - UFAM, \\ Av. General Rodrigo Octávio Jordão Ramos, 3000, Manaus, AM, Brasil \\ ${ }^{3}$ Corresponding author: Mário Henrique Terra-Araujo,e-mail: araujo.mht@gmail.com
}

TERrA-Araujo, M.H., WEBBer, A.C. \& VICENTINI, A. Pollination of Pagamea duckei Standl. (Rubiaceae): a functionally dioecious species. Biota Neotrop. 12(4): http://www.biotaneotropica.org.br/v12n4/ en/abstract?article+bn02412042012

\begin{abstract}
The floral biology, pollination and breeding system of Pagamea duckei Standl. (Rubiaceae) were studied at the Reserva Biológica da Campina, Manaus, Amazonas, Brazil. Floral morphology suggested that $P$. duckei is a distylous species. However, crossing experiments revealed that it is functionally dioecious. The flowers are actinomorphic, yellowish, produce nectar and a sweet odor, which is more intense in the morning. Anthesis started in the morning between 5.00 and 6.00 AM and extended until dusk, when the corolla tube abscissed. The flowers were visited mostly by bees of the genus Melipona. Pagamea duckei is not agamospermic and thus needs pollen vectors for effective pollination. The results of this study strengthen the idea that, in Pagamea, species with distylous flower morphology are actually functionally dioecious.
\end{abstract}

Keywords: floral biology, heterostyly, campinarana forests, Central Amazonia.

Terra-Araujo, M.H., WebBer, A.C. \& ViCEnTINI, A. Polinização de Pagamea duckei Standl. (Rubiaceae): uma espécie funcionalmente dióica. Biota Neotrop. 12(4): http://www.biotaneotropica.org.br/ v12n4/pt/abstract?article+bn02412042012

Resumo: A biologia floral, polinização e o sistema reprodutivo de Pagamea duckei Standl. (Rubiaceae) foram estudados na Reserva Biológica da Campina, Manaus, Amazonas, Brasil. A morfologia floral sugere que P. duckei é uma espécie distílica. Entretanto, cruzamentos experimentais revelaram que essa espécie é funcionalmente dióica. As flores são actinomorfas, amareladas, produzem néctar e um aroma adocicado que é mais intenso no período da manhã. A antese das flores iniciou de manhã, entre $05 \mathrm{~h} 00$ e $06 \mathrm{~h} 00$ e se estendeu até o anoitecer, quando o tubo da corola sofria abscisão. As flores foram visitadas principalmente por abelhas do gênero Melipona. Pagamea duckei não é agamospérmica e logo necessita de vetores de pólen para que haja polinização efetiva. Os resultados desse estudo fortalecem a hipótese de que muitas espécies de Pagamea com flores heterostílicas são na verdade funcionalmente dióicas.

Palavras-chave: biologia floral, heterostilia, florestas de campinarana, Amazônia Central. 


\section{Introduction}

The reproductive biology of most species has been inferred only from the morphology of flowers of herbarium specimens, and subsequent more detailed studies have revealed that morphology alone may be misleading (Barrett \& Richards 1990, Owens et al. 1993). Moreover, there may be great intraspecific variation and intermediate flower morphologies in some taxa (Contreras \& Ornelas 1999, Faivre \& McDade 2001, Wolff \& Liede-Schumann 2007). Little is known about the reproductive biology of most species in the Rubiaceae, particularly from tropical regions, and there are still very few phylogenetic studies that would allow the reconstruction of evolutionary transitions between breeding systems in the family.

The genus Pagamea (Rubiaceae) comprises approximately 30 species distributed in Tropical South America (Vicentini \& Steyermark 2004, Vicentini 2007). It is sister to the paleotropical Gaertnera, a relationship supported by morphological, anatomical and molecular data (Malcomber 2002, Vicentini 2007). These two genera form the Gaertnereae, a clade belonging to the supertribe Psychotriidinae, a well-supported clade that includes most of the heterostylous species of Rubiaceae (Robbrecht \& Manen 2006). Heterostyly is a breeding system characterized by floral dimorphism with long-styled (LS) and short-styled (SS) flowers and by obligatory xenogamy because of both self and same-morph incompatibility (Coelho \& Barbosa 2003). This breeding system evolved independently many times in the Rubiaceae (ibid.), which also include homostylous and dioecious species, making this family particularly suited for studies of breeding system evolution.

The evolution of these reproductive systems has attracted the attention of systematists who aim to understand the ecological and spatial context in which transitions between these systems occur, as well as the relation between these transitions and the diversification of the family (Anderson 1973, Bawa 1980). Naiki \& Nagamasu (2004) report, for instance, that the evolution of homostyly from heterostyly in species of Damnacanthus is correlated to polyploidy. On the other hand, the evolution of dioecy from heterostyly as seen in many genera, such as Psychotria, has been hypothesized to be the result of pollinator change (Bawa 1980). Although various hypotheses have been proposed to explain the evolution of heterostyly in the Rubiaceae (Anderson 1973), the conditions through which these evolutionary transitions happened, and how they may have promoted the diversification of the family, remain largely unknown.

Within Rubiaceae, the genus Gaertnera is more diverse than Pagamea and includes distylous and dioecious species (Malcomber 2002), while Pagamea includes homostylous, dioecious and distylous species (Vicentini 2007). However, dioecious Pagamea have distylous flower morphology, and the dioecious breeding system has been inferred by the correlations of lack of fruits in individuals with short-styled flowers, and the presence of reduced anthers with raphids instead of pollen grains in specimens with long-styled flowers (Vicentini 2007). Furthermore, the existence of homostylous species in Pagamea may be related to a breakdown in the self-incompatibility system of heterostylous species, as has been reported in Gaertnera vaginata Lam. (Pailler \& Thompson 1997).

Similarly, a reproductive biology study of Pagamea capitata Benth. in the Guyana Shield indicates that the population has homostyled flowers but is dimorphic in the size and quantity of the pollen produced (O. Hokche, personal communication). These patterns suggest that dioecy and homostyly may be derived from heterostyly in Pagamea. Although the pattern of breeding system evolution in Pagamea remains unclear due to the lack of phylogenetic resolution and ambiguity in the outgroups, the phylogeny of Pagamea indicates few transitions, with a clade of dioecious species and a grade of homostylous species (Vicentini 2007). A few exceptions are found in three widespread species of Pagamea that present intraspecific variation in breeding system, sometimes at the population level (Vicentini 2007), which are still poorly characterized. These patterns of breeding system variation in Pagamea make this clade particularly interesting for studying the evolution of breeding systems. However, it is also clear that flower morphology should be used with caution when characterizing breeding systems (Barrett \& Richards 1990, Owens et al. 1993) and, as consequence, additional studies are needed, particularly experimental studies on pollination and a better sampling of population-level intra-specific variation.

Pagamea duckei Standl. is a small tree or shrub found in whitesand Campinarana forest and is only known from two disjunct areas: one near Manaus and another close to Benjamin Constant, at the border between Brazil and Colombia (Vicentini 2007). This species is common in open Campinarana forests north of Manaus and has been described as characteristic of these forests (Anderson 1981). The floral morphology of $P$. duckei suggests dioecy (flowers with either vestigial stamens or pistils) and this species is sister to the other dioecious species of Pagamea (Vicentini 2007). This study aimed to characterize the morphology and floral biology of $P$. duckei, to test the hypothesis that it is really dioecious and to identify its visitors and pollinators.

\section{Methods}

\section{Study area}

The study was carried out at the Reserva Biológica da Campina (RBC) between November 2007 and January 2008 with the final season in December of 2008. This reserve belongs to the Instituto Nacional de Pesquisas da Amazônia (INPA) and is located $45 \mathrm{~km}$ north of Manaus, (Amazonas state). The climate is humid tropical with temperatures rarely below $18{ }^{\circ} \mathrm{C}$ and rains throughout the year. At the Reserve, white-sand, nutrient-poor soils predominate, which determines an open and scleromorphic forest known as Campinarana or Amazonian caatingas (Anderson 1981, Roberts et al. 1998).

\section{Study species}

The population of Pagamea duckei studied comprises small trees or shrubs that reaches $2-3.5 \mathrm{~m}$ in height and occur inside the Campinarana forest. The species is common at the RBC. The flowering period extended for approximately three months, (from November 2007 to January 2008), and the plants produced fruits in January.

\section{Floral morphology and breeding system}

Observations and experiments were carried out in 10 individuals of $P$. duckei over three consecutive days (November $26^{\text {th }}$ to $29^{\text {th }}$ ) with complementary observations on pollinators in December 2008. The individuals were then monitored at 15 day intervals during the flowering and fruiting period.

Marked flowers on each of these individuals were monitored for approximately 14 hours (10 hours in 2007 and 4 hours in 2008) so that we could record color, beginning and duration of anthesis, modification of floral organs during the anthesis, odor emission and visitors behavior over the day.

For anthesis characterization, 20 flowers of each "sex" were monitored at different development stages. The beginning of the anthesis was characterized by the presence of a small opening in the flower apex, stigmatic receptivity (and separation of the stigmatic lobes in pistillate flowers), or open anthers (in staminate flowers) and scent emission. Floral morphology (number, disposition and color of 
each floral whorl), was characterized in 15 flowers (fresh material) of each plant of each sex with a stereomicroscope.

Stigmatic receptivity was verified with hydrogen peroxide $\left(\mathrm{H}_{2} \mathrm{O}_{2}\right)$ $10 \%$ in 10 flowers during one day and observed with a pocket folding 20x magnifying glass (Lenzi et al. 2005). Scent emitting regions (osmophores) were detected by immersing flowers in Neutral Red for one hour and then washing them with distilled water; parts dyed in red represent the osmophores (Kearns \& Inouye 1993). Nectar was detected by direct visual inspection.

The reproductive system of Pagamea duckei was studied by controlled pollinations. To evaluate fruit formation without fertilization (i.e. agamospermy), flowers were bagged before the anthesis. Crossing between morphs (long-styled and short-styled) were impossible to perform because the long-styled flowers did not have pollen in their anthers. Cross breeding between staminate and pistillate flowers were made using pollen from flowers of other trees in the same environment. After treatments flowers were bagged to exclude floral visitors. For the natural pollination treatment (open), inflorescences were marked but not bagged. For each treatment we utilized 50 flowers at random on 10 individuals. To evaluate the reproductive success we compared hand pollination with natural pollination. The behaviors of visiting insects were recorded over 14 hours (10 hours in 2007 and four hours in 2008) and recorded insects were collected for identification at different hours over the day, or through photographs. The bees collected were then washed so as we could analyze their pollinic spectrum.

\section{Results}

\section{Floral morphology}

The species present actinomorphic flowers with four petals that were partially fused forming a small tube. The corolla lobes were reflexed at anthesis and had a creamy or greenish-yellow color externally, but were covered by long white hairs inside (Figure 1a, b). These hairs at the mouth of the corolla tube appear to restrict the access of visitors to the interior of the flowers at anthesis. Flowers were strongly dimorphic, with some individuals having very shortstyled flowers and others having long-styled flowers. Both floral morphs were similar in size (sepals and petals), and both had a bilocular superous ovary with a single ovule in each locule. The short-styled morph presented a very reduced pistil that, at anthesis, remained inside the corolla tube. The pistil of these flowers had stigmatic lobes that remained closed and that were undifferentiated from the style. Stamens were epipetalous introrsely with a yellowish colored filament and the anthers basifixed with transversal openings. The long-style floral morph had epipetalous stamens with a yellowishcream colored filament, but the anthers were extremely reduced and no pollen grains were observed. In this morph, the pistil had a long style and a well-developed bifid stigma with papilose lobes that were yellow when receptive. Stigmatic lobes were located above the petals (extrorsely) at anthesis (Figure 1b).

Flowering was diurnal and anthesis lasted one day. In shortstyled flowers the anthesis began approximately at 5.00 AM, and by 7.00 AM the flowers had opened, the corolla lobes were reflexed, and the reproductive parts were exposed. When the flowers were completely open, the petal lobes were turgid and had a yellowish color. In long-styled flowers the well-developed stigma had a paleyellow color. After anthesis the corolla darkened (brown-yellow) and suffered abscission. The long-styled flowers persisted up to 26 hours, when the ovary became reddish-green and the stigma and style yellowish-green. In short-styled flowers, the anthers were already brown-yellow colored at about 3.00 PM when petals and stamens began to fall. After corolla abscission, the sepals became red and subsequently dehydrated.

Flowers were fragrant during the whole anthesis, although this was more intense during the morning. The aroma was sweet and even nauseating. The Neutral Red test revealed areas responsible for scent production on both flower morphs, shown as red spots at the apex of the petal lobes. Nectar was observed inside the corolla tube of both floral morphs.

\section{Reproductive system}

Fruit and seed set in Pagamea duckei depended on a pollen vector between flower morphs. The reproductive system experiments indicated that this species is not apomitic. In addition, inflorescences with short-styled flowers did not formed fruits, while long-styled ones had anthers lacking pollen grains. Thus, autogamy can also be ruled out. There was fruit production resulting from hand (inter morph pollination) and natural (control) pollination. Nonetheless, the percentage of formed fruits in natural conditions was lower than on hand pollination (Table 1).

\section{Visitors and pollinators}

Flowers of Pagamea duckei were visited mostly by bees and occasionally by butterflies. The first visits to the flowers occurred early in the morning, between 5.00 AM and 5.30 AM, period in which the flowers were starting to open, but were already producing nectar.

Bees were very frequent (Table 2) and always contacted the reproductive organs in their visits. Species of the genus Melipona were the most frequent visitors (Figure 1d). These bees landed directly on the corolla lobes and introduced the head into the tube to collect nectar. While doing so, they touched the stigmatic surface with the head and abdomen (sternotrobic pollination). Pollen was also collected as a resource. At landing on the corolla lobes, they used the forelegs to collect pollen and, while still on the flower, they transferred the pollen loads to the corbiculae using the middle legs. Visits for nectar collecting lasted about two to three seconds and most of the times every open flower per inflorescence was visited.

Visits by the solitary bee genus Centris were also observed. Both male and female bees visited the flowers of Pagamea duckei (Figure 1e, f). These visits were rapid, lasting on average three seconds and male bees stayed longer in the flowers and inflorescences, while females visited flowers rapidly. Males were more frequently observed than females. Bees of the genus Trigona were also frequent, but their visits were more restricted to short-styled flowers (Figure 1g).

Butterflies visited the flowers quickly, staying on average for ten seconds in one single flower and their visitation frequency was higher in the morning (Figure 1h).

Additional observations (December 2008) yielded similar results as those of 2007 (Table 2). Meliponini bees, mainly Melipona compressipes were the most frequent floral visitors. M. compressipes had pollen loads in their corbiculae and their pollinic spectrum reveled pollen of Pagamea duckei throughout of their body, suggesting that it may be an important pollen vector for this plant species.

\section{Discussion}

\section{Dioecy vs. heterostyly}

The observed floral dimorphism in Pagamea species has been traditionally interpreted as indicative of heterostyly (Steyermark 1974), which is a common reproductive system in the Rubiaceae (Coelho \& Barbosa 2003, Teixeira \& Machado 2004b, Mendonça \& Anjos 2006, García-Robledo \& Mora 2007, Wolff \& Liede-Schumann 2007). The sister group to Pagamea, the paleotropical Gaertnera, as 

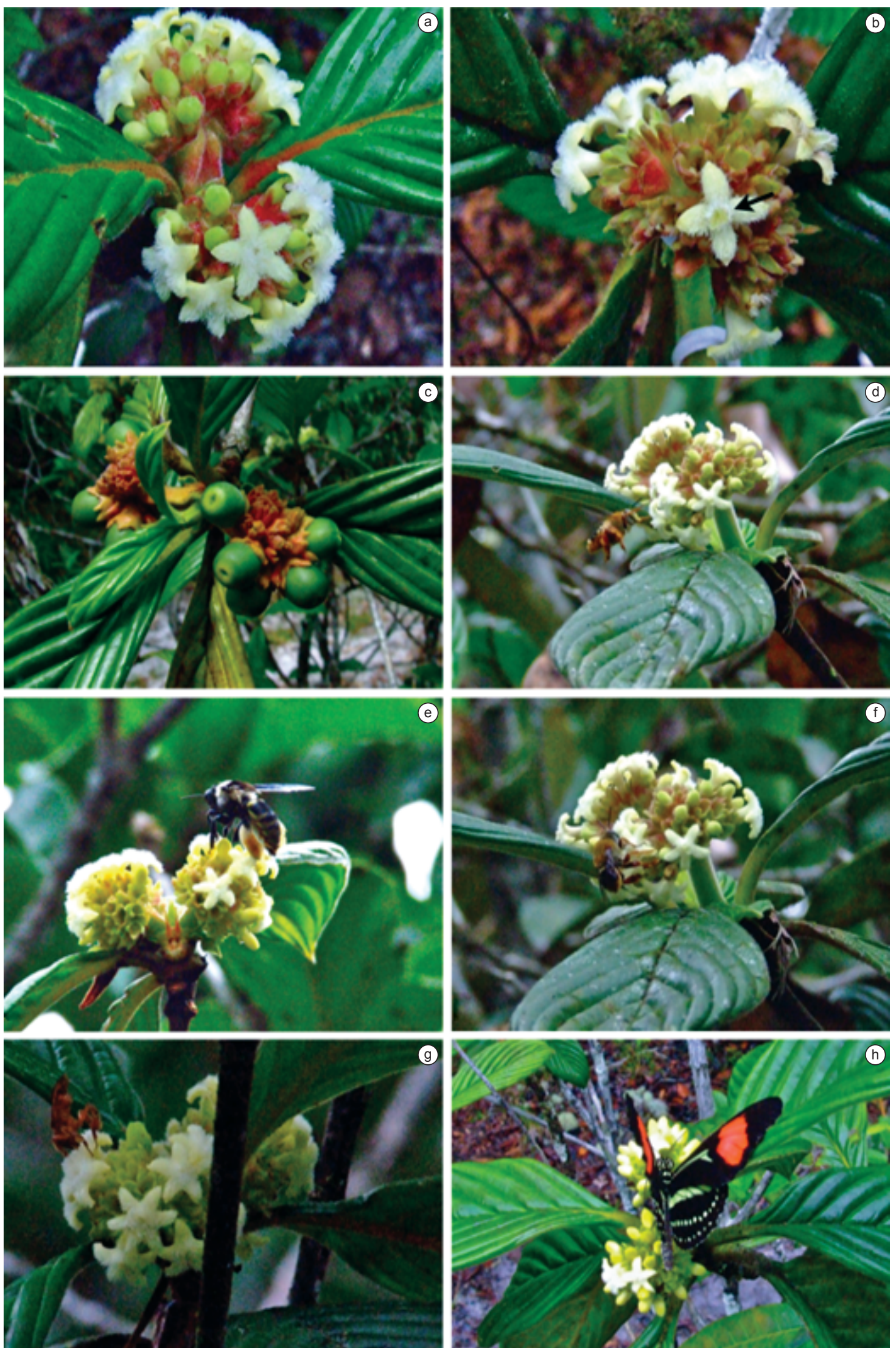

Figure 1. Flowers, fruits, and visitors in Pagamea duckei. (a) staminate flowers, (b) pistillate flowers showing the exteriorized stigma, (c) immature fruits, (d) Melipona fulva, (e) Centris sp. ㅇ, (f) Centris sp. ô, (g) Trigona williame (h) Lepidoptera sp. 1.

Figura 1. Flores, frutos e visitantes em Pagamea duckei. (a) flores estaminadas, (b) flores pistiladas destacando o estigma exteriorizado, (c) frutos imaturos, (d) Melipona fulva, (e) Centris sp. ․, (f) Centris sp. §̊, (g) Trigona williame (h) Lepidoptera sp. 1. 
well as other closely related genera (Psychotria "alliance"), include heterostyled, homostyled and dioecious species (Malcomber 2002). Vicentini (2007) reported these three reproductive systems for Pagamea but he interpreted the strongly heterostyled flowers of many species of Pagamea as functionally unisexual flowers, based on three observed characteristics: a) "short-styled" flowers have, on most dimorphic species, a very reduced pistil with closed stigmatic lobes without papillae; b) "long-styled" flowers have stamens with reduced anthers, which are packed with raphids and lack pollen; c) herbarium samples and field observations on plants with "shortstyled" flowers indicate that these never form fruit, suggesting that these flowers are staminate. Bentham (1857) had already recognized that flowers of Pagamea guianensis Aubl. 'had a tendency to become polygamous due to the abortion of feminine organs in some flowers, and occasionally the anthers in others'. The present survey confirms, with evidences from floral biology and absence of fruit formation in "short-styled" plants that the strong floral dimorphism observed in Pagamea duckei and several other species of Pagamea, is indeed indicative of dioecy.

The incorrect inference of heterostyly based only on floral morphology has been reported in several groups of plants such as Phlox, Erythroxylum, Eichhornia and Mussaenda (Barrett \& Richards 1990, Naiki \& Kato 1999), and this may be also true for many more Rubiaceae where heterostyly is considered a common breeding system. Dioecy and homostyly are the most common reproductive systems in Pagamea, but some species have morphologies suggestive

Table 1. Results of controlled pollination tests in Pagamea duckei at the Reserva Biológica da Campina, Manaus, AM.

Tabela 1. Resultado dos testes de polinização controlada em Pagamea duckei na Reserva Biológica da Campina, Manaus, AM.

\begin{tabular}{lccc}
\hline \multicolumn{1}{c}{ Treatments } & Flowers (n) & Fruits (n) & Success (\%) \\
\hline Agamospermy & 50 & 0 & 0 \\
Hand pollination & 50 & 22 & 44 \\
Control & 50 & 5 & 10 \\
\hline
\end{tabular}

of true heterostyly (Vicentini 2007). The mapping of these breeding systems on a species-level molecular phylogeny of Pagamea indicated that homostylous and dioecious species form separate clades and suggest a single origin for dioecy in this genus (Vicentini 2007). According to this phylogeny, Pagamea duckei is sister to the other species with strongly dimorphic flowers suggestive of dioecy and, hence, the functional dioecy confirmed by this study may be inferred to the other putatively dioecious species as well.

There is only one additional study about the biology and pollination of Pagamea. In contrast to the dioecious system described here, this study of a population of Pagamea capitata Benth. in the Guyana Shield, indicated that this species has homostyled flowers but which are dimorphic in the size and quantity of the pollen produced (O. Hokche, personal communication). This dimorphism is typical of heterostyled plants (distyled; Barrett \& Richards 1990), and Pagamea capitata presents homostyled and heterostyled populations (Vicentini 2007).

These patterns are in agreement with a model of evolution in which dioecy and homostyly are derived from heterostyly (Barrett \& Richards 1990).

\section{Pollination experiments}

Fruit set in Pagamea duckei was higher with hand pollination than with open pollination (Figure 1c). In Psychotria barbiflora DC. (Rubiaceae), the small number of visitors during the flowering period and the distance between pistillate and staminate plants explained the low rate of fruit production in open pollination when compared to hand pollination (Teixeira \& Machado 2004a). However, in the present study, staminate and pistillate plants were in close proximity. Hence, distance was not the limiting factor for pollen transportation. The low rate of fruit production in $P$. duckei, the large size of fruits, and the lack of the ability of selfing or apomixis may be among the causes of the restricted geographic distribution of this species. Pagamea duckei has a very restricted distribution, particularly when taking into consideration age estimates for this species $(\sim 8$ $\mathrm{Ma}$ ) and the much wider geographic distribution of younger species ( 4 Ma), which are also dioecious (Vicentini 2007). In Pagamea

Table 2. Floral visitors and visitation frequency in Pagamea duckei at the Reserva Biológica da Campina, Manaus, AM, in 2007 and 2008.

Tabela 2. Visitantes florais e frequência de visitação em Pagamea duckei na Reserva Biológica da Campina, Manaus, AM, em 2007 e 2008.

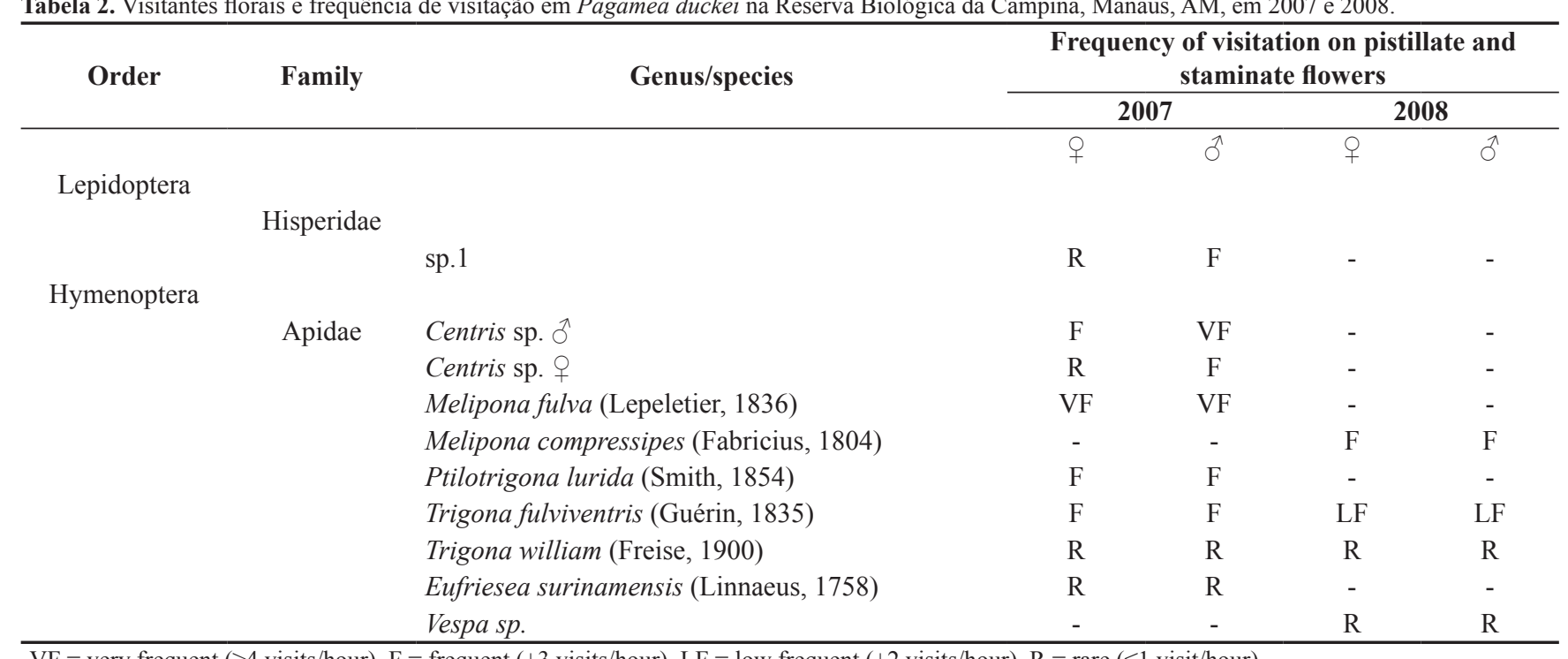

$\mathrm{VF}=$ very frequent $(\geq 4$ visits/hour $), \mathrm{F}=$ frequent $( \pm 3$ visits/hour $), \mathrm{LF}=$ low frequent $( \pm 2$ visits/hour $), \mathrm{R}=$ rare $(\leq 1$ visit/hour).

$\mathrm{VF}=$ muito freqüente $(\geq 4$ visitas/hora $), \mathrm{F}=$ frequente $( \pm 3$ visitas/hora $), \mathrm{LF}=$ pouco frequente $( \pm 2$ visitas/hora $), \mathrm{R}=\mathrm{raro}(\leq 1 \mathrm{visita} / \mathrm{hora})$. 
there is a correlation between the average number of flowers per inflorescence and geographical area, suggesting the hypothesis that the rate of range expansion may be related to fecundity (i.e. fruit number; Vicentini 2007). Higher number of flowers per inflorescence may indicate higher fecundity but it may also correlate with smaller fruits and larger array of dispersers (Vicentini 2007). Low fecundity in $P$. duckei, at least concerning the number of fruits produced also indicates the importance of these experiments for understanding the processes of diversification.

Pagamea duckei is dioecious and there was no seed formation via apomixis. Therefore, cross-polination is mandatory in this species. Many apomictic plants belong to lineages of plants that have reproductive systems of self-incompatibility, dioecy or heterostyly (Asker \& Jerling 1992 apud Bicknell \& Koltunow, 2004), and there is an evidence of apomitic formation of seeds in Coprosma, another Rubiaceae (Heenan et al. 2002). Apomixis may allow dioecious species to colonize new environments or isolated and small areas and this could be the case for Pagamea, which has an island-like distribution because of its habitat specificity (white-sand forests and savannas; Vicentini 2007). However, in Pagamea duckei there is no evidence for apomixis, which weakens any relationship with geographical distribution because the most widespread species of Pagamea are also dioecious (Vicentini 2007).

\section{Pollinators and visitors}

In Pagamea duckei, Meliponini bees (Melipona and Trigona) are the most frequent floral visitors and thus seem to be the main pollen vectors. Pollination by small bees like the Meliponini is characteristic of most dioecious species of tropical trees and shrubs (Bawa 1980). In addition, dioecious species tend to have one or few seeds per fruit, which are dispersed by birds (ibid.). Such characteristics are clearly present in $P$. duckei. The actinomorphic flowers, the corolla color ranging from white to cream, and shallow tube, presence of nectar and pollen production found in $P$. duckei are traits that fit the Melittophily syndrome. These floral characteristics are also in agreement with descriptions by Richards (1997), Machado et al. (1998) and Goldblatt \& Manning (2002) for pollination by small bees.

Melittophily has been mentioned for other Rubiaceae, mainly in Psychotria (Coelho \& Barbosa 2003, Teixeira \& Machado 2004a, Ramos \& Santos 2006). Bees seen in P. duckei flowers occur in higher frequency in the first part of the morning and this frequency increased in sunny and drier conditions. Such higher visitation rate in the morning seems to be related with higher production of nectar in this period. The synchrony between bee activity and anthesis is another indicative of the involvement of bees in the pollination process of this species (Ando et al. 2001).

Generally, species of Rubiaceae present a wide range of floral visitors (Consolaro et al. 2005). In Psychotria, many species of bees, including those of Trigona and Euglossa, and some wasps, are efficient pollen vectors (Coelho \& Barbosa 2003, Teixera \& Machado 2004a). In Amaioua guianensis Aubl., large bees such as Bombus atratus (Franklin, 1913), Centris sp., Epicharis flava (Friese, 1900) and Eulema nigrita (Lepeletier, 1841), are the most efficient pollen vectors (Amorim \& Oliveira 2006). Teixeira \& Machado (2004b) recorded seven bee species on Sabicea cinerea Aubl., pointing out mainly individuals of Euglossa cordata (Linnaeus, 1758), Xylocopa suspecta (Moore \& Camargo, 1988), Exaerete smaragdina (GuérinMéneville, 1844), Trigona fulviventris (Guérin, 1835) and a species of Pseudaugochloropsis.

Bees of the genus Centris also showed high visitation frequency, although lower when compared to Melipona. Centris females are in general oil collectors in flowers of Krameriaceae, Scrophulariaceae, Solanaceae, Gesneriaceae, Bignoniaceae and Malpighiaceae. The high number of bristles present in the forelegs of these bees makes it possible to allocate and transport oil. Male individuals do not have these bristles in the forelegs. Nevertheless, male bees collect nectar and in some cases visit flowers with the only purpose of attracting females for copulation (Gimenes \& Lobão 2006, Silva et al. 2007), and in these cases they are territorial, hardly acting as pollen vectors. The behavior of male Centris on the flowers of $P$. duckei suggests that these bees act only as floral visitors and not as pollen vector.

The floral traits of Pagamea duckei and that of most species in this genus, like the tubular corolla with free spreading lobes covered with hairs that limits the nectar robbing by small insects, and the nectar production itself, are in agreement with Psycophily (Faegri \& Van der Pijl 1979), which has been reported for other Rubiaceae (Castro \& Oliveira 2002, Goldblatt \& Manning 2002, Fenster et al. 2004). Flies, however, were not observed visiting the flowers of $P$. duckei. Additionally, pollination by Lepidoptera has been documented in Psychotria and Palicourea (Castro \& Oliveira 2002, Coelho \& Barbosa 2003), genera phylogenetically close to Pagamea (Robbrecht $\&$ Manen 2006). Nevertheless, Lepidoptera were rare visitors in $P$. duckei. Small bees, hence, appear to be the main pollinators. The strong and sweet flowers odor also supports this hypothesis.

\section{Final Considerations}

This study confirms that the strongly dimorphic flowers of Pagamea duckei represent unisexual flowers rather than distylous perfect flowers, and thus the studied population is dioecious. Observations on floral visitors showed that flowers are insectpollinated, mainly by bees, and that there is no specificity for pollinator type, with nectar as the main reward. The results here obtained suggest that other species of Pagamea with similar flower morphology are also dioecious, contributing to the understanding of breeding system variation and evolution within this clade.

\section{Acknowledgements}

We thank two anonymous reviewers for constructive comments on this paper. Carlos D'Apolito Júnior for help in the field and for many helpful comments on an early draft of the manuscript. We also thank Marcio Luiz de Oliveira for helping us with the identifications of the bees. This research was funded through a scholarship to the first author by the Conselho Nacional de Desenvolvimento Científico e Tecnológico (CNPq - 131685/2006-6).

\section{References}

AMORIM, F.W. \& OLIVEIRA, P.E. 2006. Estrutura sexual e ecologia reprodutiva de Amaioua guianensis Aubl. (Rubiaceae), uma espécie dióica de formações florestais de cerrado. Rev. Bras. Bot. 29(3):353-362. http:// dx.doi.org/10.1590/S0100-84042006000300003

ANDERSON, W.R. 1973. A morphological hypothesis for the origin of heterostyly in the Rubiaceae. Taxon 22(5-6):537-542. http://dx.doi. org/10.2307/1218628

ANDERSON, A.B. 1981. White-sand vegetation of Brazilian Amazonia. Biotropica 13(3):199-210. http://dx.doi.org/10.2307/2388125

ANDO, T., NOMURA, M., TSUKAHARA, J., WATANABE, H., KOKUBUN, H., TSUKAMOTO, T., HASHimoto, G., MARCHESI, E. \& KITCHING, I.J. 2001. Reproductive isolation in a native population of Petunia sensu Jussieu (Solanaceae). Ann. Bot. 88(3):403-413. http:// dx.doi.org/10.1006/anbo.2001.1485

BARRETT, S.C.H. \& RICHARDS, J.H. 1990. Heterostyly in tropical plants. Mem. New York Bot. Gard. 55:35-61.

BAWA, K.S. 1980. Evolution of dioecy in flowering plants. Annu. Rev. Ecol. Syst. 11:15-39. http://dx.doi.org/10.1146/annurev.es.11.110180.000311 
BENTHAM, G. 1857. Notes on Loganiaceae. J. Linn. Soc. Lond. Bot. 1:52115.

BICKNELL, R.A. \& KOLTUNOW, A.M. 2004. Understanding Apomixis: Recent advances and remaining conundrums. Plant Cell. 16:228-245. PMid:15131250 PMCid:2643386. http://dx.doi.org/10.1105/tpc.017921

CASTRO, C.C. \& OLIVEIRA, P.E.A.M. 2002. Pollination biology of distylous Rubiaceae in the atlantic rain forest, SE, Brazil. Plant Biol. 4:640-646. http://dx.doi.org/10.1055/s-2002-35433

COELHO, P. \& BARBOSA, A.A.A. 2003. Reproductive biology of Palicourea macrobotrys Ruiz and Pavon (Rubiaceae): a possible case of homostyly in the genus Palicourea Aubl. Rev. bras. Bot. 26(3):403-413.

CONSOLARO, H., SILVA, E.B. \& OLIVEIRA, P.E. 2005. Variação floral e biologia reprodutiva de Manettia cordifolia Mart. (Rubiaceae). Rev. Bras. Bot. 28(1):85-94. http://dx.doi.org/10.1590/S0100-84042005000100008

CONTRERAS, P.S. \& ORNELAS, J.F. 1999. Reproductive conflicts of Palicourea padifolia (Rubiaceae), a distylous shrub of a tropical cloud forest in Mexico. Plant Syst. Evol. 219:225-241. http://dx.doi. org/10.1007/BF00985581

FAEGRI, K. \& VAN DER PIJL, L. 1979. The principles of pollination ecology. London, Pergamon Press, 249p.

FENSTER, C.B., ARMBRUSTER, W.S., WILSON, P., DUDASH, M.R. \& THOMSON, J.D. 2004. Pollination syndromes and floral specialization. Annu. Rev. Ecol. Evol. Syst. 35:375-403. http://dx.doi.org/10.1146/ annurev.ecolsys.34.011802.132347

FAIVRE, A.E. \& McDADE, L.A. 2001. Population-level variation in the expression of heterostyly in three species of Rubiaceae: Does reciprocal placement of anthers and stigmas characterize heterostyly? Am. J. Bot. 88(5):841-853. http://dx.doi.org/10.2307/2657036

GARCÍA-ROBLEDO, C. \& MORA, F. 2007. Pollination biology and the impact of floral display, pollen donors, and distyly on seed production in Arcytophyllum lavarum (Rubiaceae). Plant Biol. 9(4):453-461. PMid:17401810. http://dx.doi.org/10.1055/s-2007-964962

GIMENES, M. \& LOBÃO, C.S. 2006. A Polinização de Krameria bahiana B.B. Simpson (Krameriaceae) por abelhas (Apidae) na Restinga, BA. Neotrop. Entomol. 35(4):440-445. PMid:17061790. http://dx.doi. org/10.1590/S1519-566X2006000400003

GOLDBLATT, P. \& MANNING, J.C. 2002. Evidence for moth and butterfly pollination in Gladiolus (Iridaceae-Crocoideae). Ann. Mo. Bot. Gard. 89(1):110-124. http://dx.doi.org/10.2307/3298660

HEENAN, P.B., DAWSON, M.I. \& BICKNELL, R.A. 2002. Evidence for apomictic seed formation in Coprosma waima (Rubiaceae). New Zeal. J. Bot. 40(3):347-355. http://dx.doi.org/10.1080/0028825X.2002.9512795

KEARNS, C.A. \& INOUYE, D. 1993. Techniques for pollination biologists. University Press of Colorado, Niwot, Colorado. 579p

LENZI, M., ORTH, A.I. \& GUERRA, T.M. 2005. Ecologia da polinização de Momordica charantia L. (Cucurbitaceae), em Florianópolis, SC, Brasil. Rev. Bras. Bot. 28(3):505-513. http://dx.doi.org/10.1590/S010084042005000300008

MACHADO, I.C.M., LOPES, A.V. \& PORTO, K.C. 1998. Reserva Ecológica de Dois Irmãos: estudos em um remanescente de Mata Atlântica em área urbana. Secretaria de Ciência, Tecnologia e Meio Ambiente, Editora da Universidade Federal de Pernambuco, Recife, 323p.

MALCOMBER, S.T. 2002. Phylogeny of Gaertnera Lam. (Rubiaceae) based on multiple DNA markers: Evidence of a rapid radiation in a widespread, morphologically diverse genus. Evolution 56(1):42-57. PMid:11913666.
MENDONÇA, L.B. \& ANJOS, L. 2006. Flower morphology, nectar features, and hummingbird visitation to Palicourea crocea (Rubiaceae) in the Upper Paraná River floodplain, Brazil. An. Acad. Bras. Ciênc. 78(1):45-57. PMid:16532206. http://dx.doi.org/10.1590/S0001-37652006000100006

NAIKI, A. \& KATO, M. 1999. Pollination system and evolution of dioecy from distyly in Mussaenda parviflora (Rubiaceae). Plant Spec. Biol. 14(3):217-227. http://dx.doi.org/10.1046/j.1442-1984.1999.00021.x

NAIKI, A. \& NAGAMASU, H. 2004. Correlation between distyly and ploidy level in Damnacanthus (Rubiaceae). Am. J. Bot. 91(5):664-671. PMid:21653421. http://dx.doi.org/10.3732/ajb.91.5.664

OWENS, S.J., JACKSON, A., MAUNDER, M., RUDALL, P. \& JOHNSON, M.A.T. 1993. The breeding system of Ramosmania heterophylla: dioecy or heterostyly? Bot. J. Linn. Soc. 113(1):77-86.

PAILLER, T. \& THOMPSON, J.D. 1997. Distyly and variation in heteromorphic incompatibility in Gaertnera vaginata (Rubiaceae) endemic to La Reunion Island. Am. J. Bot. 84(3):315-327. http://dx.doi. org/10.2307/2446005

RAMOS, F.N. \& SANTOS, F.A.M. 2006. Floral visitors and pollination of Psychotria tenuinervis (Rubiaceae): Distance from the anthropogenic and natural edges of an Atlantic forest fragment. Biotropica 38(3):383-389. http://dx.doi.org/10.1111/j.1744-7429.2006.00152.x

RICHARDS, A.J. 1997. Plant Breeding Systems. 2. ed. Chapman and Hall, London, 529p.

ROBBRECHT, E. \& MANEN, J.F. 2006. The major evolutionary lineages of the coffee family (Rubiaceae, angiosperms). Combined analysis (nDNA and cpDNA) to infer the position of Coptosapelta and Luculia, and supertree construction based on rbcL, rps16, tnrL-trnF, and atpBrbcL data. A new classification in two subfamilies, Cinchonoideae and Rubioideae. Syst. Geogr. Pl. 76:85-146.

ROBERTS, D.A., NELSON, B.W., ADAMS, J.B. \& PALMER, F. 1998. Spectral changes with leaf aging in Amazon caatinga. Trees Struct. Funct. 12(6):315-325. http://dx.doi.org/10.1007/s004680050157

SILVA, C.I., AUGUSTO, S.C., SOFIA, S.H. \& MOSCHETA, I.S. 2007. Diversidade de abelhas em Tecoma stans (L.) Kunth (Bignoniaceae): Importância na polinização e produção de frutos. Neotrop. Entomol. 36(3):331-341. PMid:17710317. http://dx.doi.org/10.1590/ S1519-566X2007000300002

STEYERMARK, J. A. 1974. Rubiaceae. In Flora de Venezuela (T. Laser, ed.). Instituto Botánico, Dirección de Recursos Naturales Renovables, Ministerio de Agricultura y Cria, Caracas, v.9, p.1-2070.

TEIXEIRA, L.A.G. \& MACHADO, I.C. 2004a. Biologia da polinização e sistema reprodutivo de Psychotria barbiflora DC. (Rubiaceae). Acta Bot. Bras. 18(4):853-862. http://dx.doi.org/10.1590/S010233062004000400016

TEIXEIRA, L.A.G. \& MACHADO, I.C. 2004b. Sabicea cinerea Aubl. (Rubiaceae): Distilia e polinização em um fragmento de floresta Atlântica em Pernambuco, Nordeste do Brasil. Rev. Bras. Bot. 27(1):193-204. http:// dx.doi.org/10.1590/S0100-84042004000100019

VICENTINI, A. \& STEYERMARK, J.A. 2004. Pagamea Aubl. (Rubiaceae). In Flora of the Venezuelan Guyana (J.A. Steyermark, P.E. Berry, K. Yatskievych \& B.K. Holst, eds.). Timber Press, Portland, v.8, p.666-678.

VICENTINI, A. 2007. Pagamea Aubl. (Rubiaceae), from species to processes, building the bridge. Thesis, University of Missouri Saint Louis, 317p.

WOLFF, D. \& LIEDE-SCHUMANN, S. 2007. Evolution of flower morphology, pollen dimorphism, and nectar composition in Arcytophyllum, a distylous genus of Rubiaceae. Org. Div. Evol. 7(2):106-123. http://dx.doi. org/10.1016/j.ode.2006.02.005 